\title{
Об особенностях загрязнения поверхностных вод на территории Дальнего Востока России
}

По данным Всемирной организации здравоохранения 80\% заболеваний людей на нашей планете связано с употреблением некачественной питьевой воды; сотни миллионов людей испытывают острый недостаток воды; из-за водных ресурсов фоксируются конфлликты между такими странами, как Египет и Эфиопия, Узбекистан и Таджикистан. В связи с этим изучение особенностей загрязнения воды является актуальным.

Объектом научных исследований данной статьи является Дальний Восток России (ДВ).

Предметом исследований является характеристика объекта (ДВ) и особенностей его природно-антропогенных условий существования.

В географическом отношении к ДВ относят те субъекты, которые входят в "притихоокеанскую часть России" [10]. Рассматриваемый регион, который протянулся с юга на север на 4,5 тыс. км и занимает площадь 3,118 млн. кв. км, делят на две части: 1) южную, куда входят Приморский и Хабаровский края, Амурская область, Еврейская автономная область, Сахалинская область, включающая Курильские острова; 2) северную, включающую Камчатский край, Магаданскую область и Чукотский автономный округ.

Цель статьи - изучение особенностей экологического состояния поверхностных вод ДВ в территориальном отношении с приоритетом в исследовании рек, озер, водохранилищ.

В изучении данной темы применялись следующие методы: статистический, гидрохимический, сравнительно-географический, картографический и другие.

Фактический материал, который использовал автор, это в основном доклады о состоянии окружающей среды за последние годы по каждому из субъектов ДВ, которые публикуются Минприроды РФ, а также публикации автора и его коллег. Следует заметить, что автор с 80-х гг. XX в. интересуется экологическим состоянием региона, вследствие чего постарался использовать сравнительный метод в широком временном диапазоне. При характеристике данной темы следует хотя бы кратко осветить те общие физико-географические условия региона, которые во многом определяют особенности загрязнения поверхностных вод: 1) его расположение в контактной зоне между самыми крупными геоструктурами Земли - континентом Евразия и Тихим океаном, что определяет наличие на значительной площади муссонного климата, в меньшей степени - морского климата, что обусловливает достаточное увлажнение; 2) это увлажнение на фоне умеренного испарения определяет развитие густой гидросети, а значит больших запасов водных ресурсов. В описании субъектов ДВ мы придерживались последовательности изложения материала с юга на север.

Приморский край [5]. Он входит в число наиболее развитых в экономическом отношении субъектов ДВ, занимая 1-ое место по численности населения (1,88 млн человек на 2020 г.), а также количеству городов -12 , уровню автомобилизации (983,5 тыс. автомобилей), развитию транспортной инфраструктуры, грузообороту и мощности топливно-энергетического комплекса (ТЭК).

Приморский край был выбран автором в качестве ключевого участка среди других субъектов ДВ, так как он характеризуется наибольшей степе-

(C) Наумов Ю. А., 2021

НАУМОВ Юрий Анатольевич, д-р геогр. наук, профессор Владивостокского государственного университета экономики и сервиса (филиал в г. Находке) (2. Находка). E-mail: naumov_ua@mail. $\mathrm{ru}$ 
Таблица 1. Основные водные ресурсы субъектов Дальнего Востока и объёмы сбрасываемых в них сточных вод (млн. кубометров)

\begin{tabular}{|c|l|c|c|c|}
\hline № & \multicolumn{1}{|c|}{ Название субъекта } & Количество рек & Количество озер & Объёмы сбросов \\
\hline 1 & Приморский край & 6000 & 4684 & 479,04 \\
\hline 2 & Хабаровский край & 8200 & 56000 & 324,15 \\
\hline 3 & Амурская область & 29000 & 25400 & 77,82 \\
\hline 4 & Сахалинская область & 65175 & 17219 & 131,5 \\
\hline 5 & Камчатский край & 112000 & 100000 & 128,29 \\
\hline 6 & Магаданская область & 260000 & 24600 & 47,34 \\
\hline 7 & Еврейская автономная область & 5017 & 3000 & 13,58 \\
\hline 8 & Чукотский автономный округ & 315425 & 252000 & 20,71 \\
\hline
\end{tabular}

Источник: $[1 ; 2 ; 3 ; 4 ; 5 ; 6 ; 7 ; 8 ; 9]$.

нью хозяйственного освоения. В связи с этим его характеристика даётся более детально.

Гидрографическая сеть края густая и включает 6000 рек длиной более 10 км, а также 4684 озера и ряд водохранилищ. Из рек самой крупной в крае является Уссури, относящаяся к бассейну р. Амур, а из озёр-Ханка (самое большое на ДВ).

Значительное загрязнение поверхностных вод отмечалось Приморгидрометом ещё в 60-70-х гг. XX в. [9]. Установлено, что из рек в наибольшей степени загрязнены Уссури и водотоки, впадающие в залив Петра Великого (Раздольная, Партизанская и др.). Например, р. Уссури во второй половине прошлого века была загрязнена френолами (5-10, временами до 80 ПДК - предельно допустимой концентрации), аммонийным азотом (3-4, временами до 70 ПДК), НП - нефтепродуктами (7-40, временами до 60 ПДК), а также соединениями меди (4-14 ПДК) и пестицидами (ДДТ - 0,59 мкг/л). Уже в XXI в. её притоки имели такое загрязнение $[5,13]$ : р. Дачная по БПК-5 (биологическому потреблению кислорода) до 38,2 ПДК, по аммонийному азоту - до 21,9 ПДК, по фосфратам - до 15,9 ПДК, в р. Спасовка по марганцу - до 49 ПДК, а по кадмию - до 4,1 ПДК.

Группа китайских и русских учёных совместно установили, что р. Уссури загрязняется как со стороны Китая, так и с территории РФ [13]. Так по НП ПДК превышалась местами в 8-22 раза. Причём за период 2008-12 гг. загрязнение соединениями азота и фосфрора увеличилось в 2-4 раза. Особенно неблагополучной является экологическая ситуация в р. Дачная, которая на протяжении многих лет оценивалась как "экстремально грязная". ПДК по железу, марганцу, ртути превышалась в ней более чем в 10 раз.

О значительном трансграничном влиянии сбросов промышленных и аграрных предприятий Китая свидетельствует также и состояние р. Раздольная, впадающей в Амурский залив. Уже на границе с Китаем вода в реке оценивается как "загрязненная", а ниже г. Уссурийск её санитарное состояние признаётся "катастрофическим": содержания по НП достигают 2-5 ПДК, по фенолам 30-40 ПДК, по нитритному азоту 20 ПДК. В её воде отмечают также повышенное содержание детергентов и пестицидов. Основными источниками загрязнения, кроме предприятий и ЖКХ Уссурийска, являются аграрные комплексы и участки складирования пестицидов. Широкий комплекс исследований, проведённых автором [12] по рекам, впадающих в залив Находка, установил, что в некоторых водотоках количество поллютантов с превышением ПДК достигает 13-14 (Партизанская, Хмыловка, Каменка). Из них самой загрязненной представляется р. Партизанская, где уровень "высокое загрязнение" (ВЗ) зафиксирован по 7 компонентам (ВВ - взвешенные вещества): 31,9 ПДК, НП - 25 ПДК, магний - 22 ПДК, ХПК, то есть химическое потребление кислорода - 21,4 ПДК, натрий - 19,3 ПДК, цинк - 16 ПДК, свинец - 15 ПДК. 
Важно заметить, что во время наводнений уровень в реках края может вырасти на 7 м, а концентрация взвешенных веществ (BВ) в десятки раз [11]. Это приводит к нарушению водоснабжения почти всех населенных пунктов края, опасности возникновения инфекционных заболеваний.

Учтем, что годовой сброс сточных вод в гидросеть края составляет 479,04 млн. кубометров (табл. 1).

Из всех городов края самый крупный-Владивосток-оказывает на гидросеть города самое сильное антропогенное воздействие. На протяжении многих лет из всего объёма его стоков очищалось всего лишь $6 \%$ и только после 2014 г. - 25\%. Вследствие этого концентрации ртути превышали ПДК в водотоке Первая Речка в 240 раз, в р. Объяснения в 200 раз, Вторая Речка от 60 до 90 раз.

Главная особенность Владивостока - он единственный город в Приморье, который получает воду из поверхностных источников. Основные водоисточники - это Пионерское, Богатинское и Артемовское водохранилища. Периодически в них отмечается загрязнения по ряду компонентов.

Около 88\% населения обеспечено доброкачественной водой. В городах чистую питьевую воду получают около $92 \%$, в сельских же поселениях эта цифрра ниже - около $75 \%$.

По сравнению с другими регионами России, в Приморье химическое загрязнение питьевой воды находится на благоприятном уровне. За последние 15 лет сброс стоков от промышленных предприятий сократился на 25-30\%.

При этом низкое качество питьевой воды отмечается в одиннадцати районах Приморского края. В питьевой воде часто отмечают значительное превышение ПДК по железу. Но это связано не столько с самими водоисточниками. Мягкая питьевая вода, проходя по трубам, вступает в реакцию с коррозией металла, и выщелачивает её. Происходит вторичное загрязнение воды.

Кроме того, некачественная питьевая вода обусловлена устаревшим оборудованием на водоочистных станциях или их полным отсутствием. В 2019 г. в питьевой воде Приморского края не регистрировалось превышений гигиенических нормативов по содержанию тяжелых металлов, не обнаружено патогенной и условно патогенной микрофлоры, возбудителей паразитарных инвазий, степень потенциальной эпидемической опасности питьевой воды в целом по Приморскому краю в течение 3-х лет оценивается как средняя.

В централизованных системах водоснабжения Приморского края было зафриксировано несоответствие нормативам по санитарно-химическим показателям в $31,6 \%$ взятых проб, по микробиологическим показателям - в 8,8\% проб. В нецентрализованных системах водоснабжения не соответствовало нормативам качества в 40,2\% проб по санитарно-химическим показателям и в $52,1 \%$ проб по микробиологическим показателям.

Хабаровский край [7]. Численность его населения составляет 1,3 млн человек. Край выделяется развитым машиностроением, горно-добывающей промышленностью и металлургией. Город Хабаровск является центром машиностроения ДВ и самым крупным в регионе по населению (618 тыс. человек). Основной вклад в сбросы (общий объём 324,15 млн. кубометров) от стационарных источников (сл. табл. 1) вносят ТЭК (Хабаровская ТЭЦ-1, ТЭЦ-3, многочисленные котельные), Хабаровский нефтеперерабатывающий завод - НПЗ и предприятия машиностроения.

Поверхностные водные объекты на территории края представлены огромным количеством водотоков (более 200 тысяч) общей длиной 550 тыс. км, в том числе 142 - длиной более 100 км, 8200 - длиной более 10 км. Река Амур - главная речная артерия не только края, но и всего региона. Его длина 2824 км, общая площадь бассейна 1855 тыс. кв. км. Устье реки доступно для морских судов, которые могут подниматься по большой воде до г. Хабаровска. Водные объекты, расположенные на территории края, используются на нужды промышленности, сельского хозяйства и населения (водозабор и водоотведение, шахтный водоотлив), а также для судоходства, рекреации, рыборазведения.

Серьезной экологической проблемой является возникновение чрезвычайных ситуаций в результате наводнений.

Сложная водохозяйственная ситуация складывается на реках бассейна p. Амура, который традиционно относится к одним из наиболее паводкоопас- 
ных районов в России. Периодически затоплению и загрязнению водозаборов подвергаются отдельные территории городов Хабаровска, Комсомольска-на-Амуре, Николаевска-на-Амуре, Бикина, 157 населенных пунктов края с населением около 80 тыс. человек, хозяйственные объекты и более 40 тыс. га сельскохозяйственных угодий.

Крупные наводнения, с высоким уровнем стояния вод, произошли в последние десятилетия - в 1976, 1984, 1989, 2004, 2009 гг., но самое катастрофическое в 2013 г.: 4 сентября уровень воды у г. Хабаровск достиг 808 см (рекордный уровень, зафиксированный в 1897 г., составлял 642 см). В результате погибло 85 человек, пропало без вести 105 человек, а 840 тысяч человек было эвакуировано. Зоны бедствия охватили в РФ Хабаровский и Приморский края, Амурскую область и Еврейскую автономную область. Только для сельского хозяйства ущерб составил более 10 млрд. рублей.

Бытовое водопотребление на душу населения в Хабаровском крае - 75,913 м³/год на человека, что выше как показателя фредерального округа (66,583 м³/год на человека), так и среднероссийского показателя $\left(56,205 \mathrm{~m}^{3} /\right.$ год на человека).

Река Амур является наиболее важным водохозяйственным объектом для городов Хабаровск, Комсомольск-на-Амуре, Николаевск-на-Амуре, где сконцентрировано большинство промышленных предприятий. В районе сброса сточных вод этих предприятий в р. Амур наблюдаются повышенные концентрации железа общего, фенолов, алюминия, азота аммонийного, азота нитритного, меди. Промпредприятия и водоканалы выше перечисленных городов сбрасывают в поверхностные воды смесь хозяйственно-бытовых и промышленных сточных вод, которые имеют в своем составе широкий спектр загрязняющих веществ.

Ухудшение качества воды в Амуре и его крупных притоках обусловливают снижение рыбохозяйственного и рекреационного потенциалов. Санитарно-эпидемиологическая обстановка в регионе расценивается как стабильно-напряженная. Качество воды в Амуре по микробиологическим показателям постоянно ухудшается. Участились за последние годы фракты выделения в пробах воды из Амура возбудителей вирусных инфекционных заболеваний. За последние 40-50 лет в связи со значительным по интенсивности хозяйственным освоением природных ресурсов, строительством новых и увеличением производственных мощностей действующих промышленных и агропромышленных предприятий, развитием городов и населенных пунктов, созданием прудов, водохранилищ, вырубкой на больших территориях лесных массивов, воздействие на геоэкосистемы водосбросов возросло, и стала заметной их антропогенная деградация. Объем загрязнения сточных вод по Хабаровскому краю, сбрасываемых в поверхностные объекты, составил в отчетном году 187,68 млн. м $^{3}$, загрязненных без очистки $-44,13$ млн. м $^{3}$. В водные источники, используемые для питьевого водоснабжения, поступают металлы, НП, детергенты, соединения азота, фосфора и др. Объем сброса недостаточно очищенных сточных вод по Хабаровскому краю составил в 2011 г. 143,54 млн. м $^{3}$. В разрезе отраслей наибольшие объемы сброса сточных вод отмечаются на предприятиях ЖКХ - 50,9 \% от общего объема сброса сточных вод по краю; на предприятиях промышленности, теплоэнергетики, др. отраслях $-49 \%$, сельского хозяйства - 0,1\%. Ежегодно отмечается, что в коммунальном хозяйстве теряются значительные объемы воды $-83 \%$ от общего объема потерь по краю, что связано с изношенностью водопроводных сетей, несовершенством запорной аппаратуры. Отсутствие достаточного фонансирования не позволяет предприятиям ЖћКХ выполнять работы по замене водопроводных сетей в требуемых объемах.

Амурская область [1]. Численность населения области составляет 782 тыс. человек. В г. Благовещенск основные источники загрязнения поверхностных вод: Благовещенская ТЭЦ, котельные, предприятия пищевой отрасли. В связи с этим объемы сточных вод достигают 77, 82 млн. кубометров (cм. табл. 1).

По территории области протекает 2628 рек длиной более 10 км, в том числе 31 протяженностью более 200 км. Крупнейшие реки области длиной более 500 км: Амур, Зея, Бурея, Селемджа, Гилюй, Олекма, Нюкжа. На территории области сосредоточено 25,4 тысячи озер. 
Искусственные водные объекты представлены тремя крупными водохранилищами: Зейским, Бурейским и Нижне-Бурейским. В 2019 г. сброс сточных вод, включая шахтно-рудничные и коллекторно-дренажные, составил 77,82 млн. м3, в том числе в поверхностные водные объекты Амурской области - 75,26 млн. м3, что на $3 \%$ (2,16 млн. м3) больше чем в 2018 г.

В 2019 г. отмечается значительное увеличение сброса тяжелых металлов, за исключением свинца и цинка.

Увеличение марганца $(+146,9 \%)$ и железа $(+262,5 \%)$ связано с деятельностью АО "Амурский уголь".

Увеличение содержаний меди $(+10,1 \%)$ обусловлено также её концентрацией в карьерно-дренажных водах угольных разрезов.

Сброс хрома увеличился за счет сточных вод п. Новобурейский (МУП "Флагман") в связи с увеличением их объёма.

Сброс ВВ увеличился за счет карьерно-дренажных вод Ерковецкого угольного разреза АО "Амурский уголь".

В структуре забора воды по видам экономической деятельности большая доля потребления воды приходится на отрасли: 1) добыча полезных ископаемых $-48,5 \%$; 2) водоснабжение - 42,27 \%; 3) теплоэлектроэнергетика - 9,24 $\%$; 4) остальные отрасли - по 1-2\%.

Систематические наблюдения за гидрохимическим режимом р. Амур в пределах Амурской области осуществляются в 3-х пунктах: с. Игнашино, $\quad$ с. Черняево и г. Благовещенск.

Наибольшую долю в общую оценку степени загрязненности воды внесли соединения меди, алюминия, марганца и џинка, а также трудноокисляемые органические вещества (по ХПК).

Качество воды у села Игнашино характеризуется 3-м классом с разрядом "б" и вода, аналогично предыдущему году, классифицируется как "очень загрязненная". На уровне характерного загрязнения (100 \%) присутствовали в воде аммонийный азот и соединения алюминия, их среднегодовые величины составляли 2 ПДК и 2,5 ПДК (в 2018 г. - 1 ПДК и 1,8 ПДК).

Критический уровень достигнут по содержанию алюминия.

У г. Благовещенск в р. Амур среднегодовые концентрации соединений цинка и алюминия возросли до уровней 2,4 и 2,8 ПДК соответственно, в 2018 г. - 1,8 и 1,9 ПДК. В тоже время относительно предыдущего периода наблюдений снизились максимальные и средние за год концентрации соединений железа соответственно в 4,4 и 1,4 раза, меди - в 1,5 и 1,3 раза. В 5 км ниже города загрязненность соединениями цинка возросла от 25 до $41 \%$ по числу случаев превышения ПДК, по соединениям алюминия - от 85 до 91 \%. Среднегодовые концентрации данных показателей также возросли от значений менее 1 ПДК до 1,8 ПДК и от 2,1 ПДК до 3,4 ПДК соответственно. Основным поставщиком загрязняющих веществ техногенного происхождения на рассматриваемом участке р. Амур с российской стороны является г. Благовещенск. Подавляющая часть загрязненных сточных вод поступает от АО "Амурские коммунальные системы" - 21533 тыс. м $^{3} 2019$ г. (около 96,9 \% от общего объема по городу). Сточные воды загрязнены органическими веществами, азотом аммонийным, фосоратами, нитритами.

Вода в Зейском водохранилище в целом в 2019 г. отнесена к 3 классу разряду "a" и оценена как "загрязненная". Характерными загрязняющими веществами были трудноокисляемые органические вещества, соединения железа, меди, алюминия и марганца, с нарушением норматива в 57-99 \% проб воды. Отмечалась устойчивая загрязненность азотом аммонийным (32\%) со средними значениями концентрации на уровне 1 ПДК и неустойчивая со среднегодовыми концентрациями менее 1 ПДК с нарушением норматива в 7-14 \% проб.

Качество воды осталось на уровне 2018 г.: "очень загрязненная" 3-й класс, разряд "б".

В 2019 г. значительно возросли среднегодовые и максимальные концентрации соединений марганца до 7,7 ПДК и 19,4 ПДК соответственно, в 2018 г. соответствовали 1,8 ПДК и 2,5 ПДК. Качество воды в р. Бурея у с. Саскаль ухудшилось, разряд "а" сменился на разряд "б", но в пределах 3-го класса и вода оценивается как "очень загрязненная". В химическом составе воды есть некоторые изменения, которые проявились в увеличении среднего- 
довой концентрации соединений алюминия до уровня 3,6 ПДК, максимальная величина на уровне 11,1 ПДК (уровень ВЗ - высокого загрязнения), в 2018 г. концентрации были на уровне 1,8 ПДК и 2,8 ПДК соответственно. Характерный уровень загрязненности отмечается соединениями железа, алюминия и марганца (с частотой нарушения норматива в 60-100 \%), их средние за год концентрации составляли соответственно 10,5 ПДК, 3,6 ПДК и 1,9 ПДК, в 2018 г. были на уровне 8,7 ПДК, 1,5 ПДК, 1 ПДК. У города Зея качество воды р. Зея значительно улучшилось. Количество загрязняющих веществ на уровне 2018 г.: 8 из 17, учитываемых в комплексной оценке. Загрязнение соединениями цинка от характерного уровня (93 \% повторяемости превышений ПДК) перешло к неустойчивому (14,3\%). Среднегодовая концентрация снизилась с 5,6 ПДК до значения менее 1 ПДК, максимальная - с 19,3 ПДК до 1,5 ПДК. Относительно 2018 г. средняя концентрация соединений меди уменьшилась в 8,3 раза, максимальная - в 24 раза. Характерными загрязняющими веществами (с повторяемостью 50-100 \%) являлись трудноокисляемые органические вещества и азот аммонийный. Кроме того, характерная загрязненность отмечалась по соединениям железа, меди, алюминия и марганца с повторяемостью нарушения норматива в 57-100 \% проб воды. Случаев ВЗ и ЭВЗ не обнаружено. Критический уровень загрязненности достигнут по соединениям алюминия в обоих створах.

У города Свободный качество воды в реке осталось на уровне 2018 г. -3 класс, разряд "б" и характеризуется как "очень загрязненная". Характерный уровень загрязненности соединениями меди (64 \%) сменился неустойчивым (36 \%) загрязнением, среднегодовая концентрация уменьшилась незначительно - с 1,5 ПДК в 2018 г. до 1 ПДК в 2019 г., максимальная концентрация несколько повысилась и составила 4,1 ПДК, в 2018 г. - 3,8 ПДК.

Качество воды в р. Зея у г. Благовещенск ухудшилось: в обоих створах разряд "а" сменился на разряд "б" ("очень загрязненная") в пределах 3-го класса. Сохранилась характерная загрязненность трудноокисляемыми органическими веществами, азотом аммонийным, соединениями железа, меди, цинка, алюминия и марганца. В створе 1 км выше города выявлено 2 случая высокого загрязнения соединениями алюминия (11 ПДК) и цинка (13 ПДК). На изучаемом участке в створе 0,5 км ниже ст. Бурея выявлен случай ЭВЗ на уровне 62,7 ПДК и случай высокого загрязнения соединениями марганца на уровне 36,3 ПДК в створе 0,2 км выше ст. Бурея. Возросли среднегодовые и максимальные концентрации марганца до 13 ПДК и 49 ПДК соответственно, в 2018 г. составляли 10 ПДК и 36 ПДК соответственно. На данном участке реки выявлены случаи В3 по соединениям алюминия на уровне 10,6 и 11,6 ПДК, марганца - 48,8 ПДК и цинка - 15 ПДК. Кроме того, загрязняющие вещества поступают в реки с талыми водами из отвалов угольных разрезов АО "Амурский уголь", расположенных в пойме реки. В 2019 г. значительно снизилось содержание соединений цинка. Максимальная концентрация в 2018 г. достигала уровня ВЗ и составляла 16 ПДК, в отчетном году - 8,5 ПДК. При этом среднегодовые концентрации по таким показателям, как органические вещества (по ХПК), азот аммонийный, железо общее, соединения меди, алюминия и марганца, выше, чем в 2018 г. Критический уровень загрязненности воды был достигнут по содержанию алюминия и железа, среднегодовые концентрации которых увеличились по сравнению с 2018 г. от 6 до 8 ПДК и от 8 до 9 ПДК соответственно. В то же время отмечено снижение загрязненности соединениями марганца, среднегодовая концентрация которого уменьшилась почти в 3 раза и составила 2,8 ПДК (в 2018 г. - 7,4 ПДК).

Для водных объектов области характерна загрязненность соединениями меди, марганца, железа, цинка, алюминия. Загрязненность данными показателями встречается практически в каждом водном объекте и имеет разный уровень загрязненности по кратности превышения ПДК.

Еврейская автономная область (EAO) [2]. Численность её населения 156 тыс. человек. Реки бассейна испытывают большую антропогенную нагрузку. Основными виновниками загрязнения поверхностных вод бассейна Амура остаются золотодобывающие предприятия, промышленные центры и угледобывающие предприятия, расположенные в верховьях Амура, а также железнодорожный транспорт, предприятия пищевой промышленности, объ- 
екты коммунального хозяйства. В связи с этим объёмы сбросов сточных вод составляют 13,58 млн. кубометров (сл. табл. 1).

В городе Биробиджан основной вклад в сбросы от стационарных источников вносят Биробиджанская ТЭЦ, завод силовых трансформаторов, а также предприятия ЖКХ. Кроме того, реки этого субъекта оказывают частичное трансграничное влияние на р. Сунгари. Ее водосбор целиком находится на территории Китая. Качественный состав этого притока формируется под влиянием сброса сточных вод населенных пунктов КНР и поверхностного стока с территории, активно используемой сельскохозяйственными предприятиями.

В соответствии с Программой мероприятий по осуществлению совместного российско-китайского мониторинга в 2019 г. пробы воды для оценки влияния р. Сунгари отбирались в двух створах: 1) с. Амурзет - г. Миншань (фоновый створ). По сравнению с 2018 г. качество воды р. Амур не изменилось; 2) с. Нижнеленинское - г. Тунцзян (контрольный створ). Качество воды в 2019 г. улучшилось на один класс (2-й класс "слабо загрязненная"). Как и в прошлом году, основными загрязняющими веществами являлись органические вещества, аммонийный азот, железо, медь, цинк и марганец.

Воды рек EAO в основном характеризовались средним уровнем загрязненности по большинству показателей. Низкий уровень наблюдался по органическим веществам (ХПК и БПК-5), соединениям азота. Основной объем сброса сточных вод в водные объекты осуществляется предприятиями ЖКХ и относится к хозяйственно-бытовым стокам. На их долю приходится более 90\% всех сбросов. Основными загрязняющими веществами, поступающими в водные объекты с данных предприятий, являются следующие: БПК полное, взвешенные вещества, азот аммонийный, нитриты, нитраты, железо, жиры, детергенты, фосфраты.

Многие из существующих очистных сооружений построены более 30 лет тому назад и не отвечают современному уровню развития. Крупнейшим источником сброса загрязненных сточных вод является МУП "Водоканал" города Биробиджана, на долю которого приходится более $68 \%$ всех канализационных стоков области.

Качество питьевых подземных вод на водозаборах не вызывает особых опасений, за исключением естественных природных некондиций.

Наихудшая ситуация с загрязнением питьевой воды железом и марганцем складывается в Ленинском районе (40,4 и 50,0 \% неудовлетворительных проб соответственно), Биробиджанском районе (52,5 и 11,3\%), Октябрьском ( 38,9 и $47,1 \%$ ) и Смидовичском районах $(44,2$ и $51,9 \%$ ).

Ухудшается ситуация с микробным загрязнением питьевой воды. Доля неудовлетворительных проб в источниках централизованного водоснабжения увеличилась в 2019 г. до 9,7\%, тогда как она составляла лишь 3,7\%.

Причинами низкого качества питьевой воды являются в первую очередь фракторы природного характера: 1) повышенное содержание в воде водоносных горизонтов соединений железа и марганца; 2) отсутствие эфрфективной водоочистки в отношении растворенных вредных химических веществ (нитраты); 3) отсутствие или ненадлежащее состояние зон санитарной охраны водоисточников; 4) высокая изношенность водопроводов и разводящих сетей, приводящая к вторичному загрязнению воды.

Сахалинская область [6]. Численность населения 488 тыс. человек. Этот регион является единственным островным в РФ. Он в наибольшей степени страдает от загрязнения нефртегазодобычи. В г. Южно-Сахалинск основные источники загрязнения: ТЭК, предприятия рыбной промышленности и ЖКХ. Река Охинка (г. Оха) стала одной из самых загрязненных рек о. Сахалина. Источниками загрязнения водоема являются недтедобывающие предприятия, которые расположены по всей длине реки. Причинами загрязнения являются отсутствие необходимых очистных сооружений, неудовлетворительная работа имеющихся, а также открытая система нефтесбора, потери нефти при транспортировке. В отчетном году среднегодовые концентрации НП снизились почти в два раза и находились на уровне 89,2 ПДК, но по-прежнему фиксируются на уровне ЭВЗ. В 2019 г. отмечено 9 случаев ЭВЗ по НП (от 55,0 ПДК до 416 ПДК) и 1 случай - медью (53,7 ПДК). Отмечено 5 случаев высокого загрязнения НП - от 32,0 ПДК до 42,8 ПДК. Установлено, что общий объём 
сбросов сточных вод составил 131,5 млн. кубометров (сл. табл. 1). Общая обстановка по рекам такая.

Река Бирюкан (с. Восточное). Качество воды реки осталось на прошлогоднем уровне, вода реки относится к 3-му классу, разряд Б, очень загрязненная. В 2019 г. среднее содержание железа общего снизилось до 1,5 ПДК, азота нитритного возросло до 1,3 ПДК, соединений меди - до 4,8 ПДК, марганца - до 3,3 ПДК.

Река Эрри (с. Тунгор). Коэффициент комплексности загрязненности воды снизился до $25,7 \%$. Качество воды реки улучшилось, вода из 3-го класса, разряд Б, очень загрязненная, перешла к 3-му классу, разряд А, загрязненная. В отчетном году среднее содержание железа осталось на уровне прошлого года (3,1 ПДК), соединений меди снизилось до 5,1 ПДК, НП - до 1,0 ПДК, марганца возросло до 3,2 ПДК.

Камчатский край [3]. Его население составляет 313 тыс. человек. Здесь основным источником антропогенного загрязнения поверхностных вод является ТЭК. Объём сбросов сточных вод достигает 128,29 см. кубометров (сл. табл. 1). Речная сеть Камчатского края хорошо развита и принадлежит к бассейнам Тихого океана, Охотского и Берингова морей. Наиболее крупными и значимыми реками полуострова являются река Камчатка (длина 758 км) и река Пенжина (длина 713 км). На территории края насчитывается более 112 тыс. озер. Самым крупным озером является озеро Нерпичье. К загрязняющим веществам для всех водоемов полуострова, как и в 2017 г., отнесены НП, dpeнолы и соединения меди.

Среднегодовое содержание НП для $72 \%$ обследованных рек снизилось в 2,0-7,5 раз и только в р. 1-я Мутная увеличилось в 3 раза (до 5 ПДК). Наибольшее количество НП было выявлено в главном водотоке бассейна р. Озерная и в ее притоке (замыкающий створ р. Паужетка) - в среднем 12,5 и 13,0 ПДК.

В отчетном году в дождевой паводок было зафиксировано всего два случая высокого загрязнения НП: в р. Озерная - 48, 8 ПДК и в замыкающем створе р. Паужетка - 46,4 ПДК.

Фенолы являлись характерным загрязняющим веществом. Их средние за год величины, рассчитанные для $73 \%$ рек, увеличились в $1,5-4,5$ раза, а для р. 1-я Мутная - в 7 раз.

В 41\% обследованных водотоков содержание соединений меди снизилось в 1,5-3 раза, в остальных - не изменилось.

Цинк, как и в прошлом году, был загрязняющим веществом почти для всех исследуемых рек. Средняя за год концентрация данного металла для всех водотоков не превышала 2,3 ПДК.

Как и в 2017 г., органические вещества по БПК-5 и ХПК содержались в воде рек полуострова практически в одинаковой степени, их концентрации выше допустимой были не более 2,5 и 1,8 ПДК соответственно. Кислородный режим рек в течение года был хорошим. Только в семи пробах воды, отобранных в различные гидрологические сезоны в реках, дефицит насыщения воды кислородом составил $4-11 \%$.

В 2018 г. вода рек Камчатка (п. Козыревск) и Паужетка (выше и ниже п. Паужетка) стала чище и перешла в категорию "загрязненных". Также изменилась вода притоков реки Камчатка (реки Берш, Уксичан и Анавгай) - из категории "загрязненных" перешла в "слабо загрязненные". Ввиду роста основных показателей степени загрязненности вода рек Авача ниже г. Елизово и Красная перешла в категорию "очень загрязненных". В текущем году ухудшилось качество воды на участках рек Корякская и Ключевка. Таким образом, вода этих рек из категории "слабо загрязненных" перешла в "загрязненные". Доля населения, обеспеченного доброкачественной питьевой водой в крае, составила 99,69\%.

Магаданская область [4]. Численность ее населения составляет 139 тыс. человек. Основные источники сбросов общим объемом 47,34 млн. кубометров (см.табл.1) представлены многочисленными предприятиями горнодобывающей промышленности и ЖКХ. Густая речная сеть области принадлежит бассейнам Северного Ледовитого и Тихого океанов. Самая многоводная - Колыма, длина реки 2129 км. На территории области насчитывается 6 водохранилищ, наиболее крупное из них - Колымское водохранилище. В 2019 г., уровень загрязненности поверхностных вод бассейна р. Колыма и материковой 
части побережья Охотского моря, по сравнению с 2018 г., существенно не изменился. По-прежнему к характерным загрязняющим веществам относились соединения железа, марганца, меди, нефтепродуктов и аммонийного азота. В единичных створах некоторых водных объектов увеличилось количество случаев высокого загрязнения воды соединениями меди, марганца, свинца и взвешенными веществами.

По другим рекам экологическая ситуация такова: "грязная" вода (4-й класс качества, разряд "а" и "б"): р. Берелех, р. Талок, р. Тенке, р. Омчак, р. Детрин, p. Дебин, p. Средникан, р. Тауй, водохранилище р. Колымское, р. Оротукан; "загрязненная" и "очень загрязненная" (3-й класс качества, разряды "а" и "б"): р. Кулу, р. Сугой, р. Омчикчан, р. Ола, р. Дукча, р. Магадана, p. Каменушка, водохранилище р. Каменушка, р. Армань, р. Хасын.

Первое место в водопотреблении занимают предприятия, осуществляющие добычу драгоценных металлов - 35,72 \%; на втором месте - ТЭК - 29,69 \%; на третьем - предприятия, занимающиеся рыбоводством и воспроизведением биоресурсов - 6,22 \%; на четвертом - предприятия ЖКХ - 5,9\%; прочие $-1,13 \%$.

Чукотский автономный округ (ЧАО) [8]. Этот субъект является самым малонаселенным (49,5 тыс. человек) и наименее освоенным в хозяйственном отношении на ДВ. Анализ таблищь 1 показывает, что в связи с этим из всех субъектов Чукотка характеризуется наименьшим объемом сбросов сточных вод с учетом площади субъекта. Забор пресной воды в 2017 г. составил 17,82 млн. $\mathbf{M}^{3}$, что на $4,8 \%$ больше, чем в 2016 . все водные объекты относятся к бассейнам Восточно-Сибирского, Чукотского и Берингова морей, к бассейну Охотского моря относится лишь небольшой отрезок р. Миритвеем. Крупнейшими реками Чукотки в бассейне Северного Ледовитого океана являются реки бассейна Колымы - Большой Анюй и Малый Анюй, Омолон. В бассейне Тихого океана это р. Анадырь с притоками. Крупнейшими озёрами Чукотки являются Красное и Пекульнейское. Жемчужиной Чукотки называют уникальное озеро Эльгыгытгын, представляющее собой затопленный метеоритный кратер. Число искусственных водоёмов незначительно, крупнейшими из них являются Билибинское водохранилище. Обеспеченность населения Чукотского автономного округа ресурсами речного стока - 3818,011 тыс. $\mathrm{m}^{3} /$ год на человека, что значительно выше как среднероссийского показателя $(31,717$ тыс. м ${ }^{3} /$ год на человека), так и показателя ДВФО (310,704 тыс. м³/год на человека). По этому показателю Чукотский АО занимает первое место среди регионов фредерального округа.

Ниже представлена динамика водопотребления в регионе в 20102015 гг. Сброс сточных вод в водные объекты Чукотки - 20,74 млн. м3, из них 80,38\% - условно-чистые и нормативно-очищенные сточные воды и $19,62 \%$ - загрязнённые и недостаточно-очищенные. В централизованных системах водоснабжения Чукотского АО было зафиксировано несоответствие нормативам по санитарно-химическим показателям в $51,2 \%$ взятых проб, по микробиологическим показателям - в $0,8 \%$ проб. В нецентрализованных системах водоснабжения не соответствовало нормативам качество в $36,2 \%$ проб по санитарно-химическим показателям.

Основная доля проб воды питьевой с превышением гигиенических нормативов по содержанию железа приходится на концентрации железа 1-2 ПДК-17,9\%, 12,6\% проб с концентрацией железа 2,1-5 ПДК, 5,2\% проб с концентрацией железа более 5 ПДК.

Концентрации железа, превышающие более 5 ПДК, обнаружены в питьевой воде в г. Певек.

Всего за 2018 г. исследованы 159 проб по микробиологическим показателям, не соответствующих гигиеническим нормативам $0,62 \%$; по санитарно-химическим показателям исследованы 71 проб, с превышением гигиенических нормативов 64,7\% (2017 г. - 79,1\%, 2016 г. - 81,2\%), темп прироста к 2017 г. отрицательный $(-22,25 \%)$.

\section{Заключение}

Статистика охарактеризованных выше государственных докладов показывает, что ДВ обладает огромными запасами водных ресурсов. 
В результате анализа и обобщения собранных нами материалов установлены следующие особенности состояния поверхностных вод ДВ:

1) На 1-м месте по загрязнению этих вод стоит Приморский край.

2) Трансграничному загрязнению преимущественно со стороны Китая подвержена южная часть региона (Приморский и Хабаровский края, Амурская область).

3) Среди городских вод максимальное загрязнение характерно для Владивостока, как крупного промышленного центра ДВ.

4) Из всех поллютантов наиболее распространенными являются взвешенные вещества, детергенты, нефтепродукты, соединения железа, меди, цинка, алюминия, свинца, ртути, марганца, фоссрора и азота, но, в зависимости от их происхождения (от сгорания топлива, переноса ветром с угольных терминалов или от цементных заводов), они по-разному воздействуют на организм человека.

5) Особо опасным является поступление загрязняющих веществ (металлов, недтепродуктов, детергентов, соединения азота, фросфора и др.) в питьевые источники.

6) Среди стационарных источников загрязнения на первом месте по сбросам лидируют ЖКХ и горнодобывающие предприятия, вот почему их модернизация, которая с разным темпом происходит во всех субъектах региона , является весьма актуальной.

7) Вызывает тревогу, что во всех субъектах отмечается изношенность канализационной и водопроводной сетей, а также очистных сооружений.

\section{Литература}

1. Доклад о состоянии окружающей среды в Амурской области в 2019 году. Благовещенск: Министерство природных ресурсов и экологии Амурской области, 2020. $136 \mathrm{c}$.

2. Доклад о состоянии окружающей среды в Еврейской автономной области в 2017 году. Биробиджан: Министерство природных ресурсов и экологии Еврейской автономной области, 2020. $142 \mathrm{c.}$

3. Доклад о состоянии окружающей среды в Камчатском крае в 2018 году. Петропавловкс-Камчатский: Министерство природных ресурсов и экологии Камчатского края, 2019. 370 с.

4. Доклад о состоянии окружающей среды в Магаданской области в 2015 году. Магадан: Министерство природных ресурсов и экологии Магаданской области, 2020. $187 \mathrm{c.}$

5. Доклад о состоянии окружающей среды в Приморском крае в 2019 году. Владивосток: Департамент природных ресурсов и экологии Приморского края, 2020.221 с.

6. Доклад о состоянии окружающей среды в Сахалинской области в 2019 году. Южно-Сахалинск: Министерство природных ресурсов и экологии Сахалинской области, 2020.170 с.

7. Доклад о состоянии окружающей среды в Хабаровском крае в 2019 году. Хабаровск: Министерство природных ресурсов и экологии Хабаровского края, 2020. 208 с.

8. Доклад о состоянии окружающей среды в Чукотском автономном округе в 2017 году. Анадырь: Министерство природных ресурсов и экологии Чукотского автономного округа, 2018. 117 с.

9. Долговременная программа охраны природы и рационального использования природных ресурсов Приморского края до 2005 года. Экологическая программа. Часть 2. Владивосток: Дальнаука, 1993. 301 с.

10. Ивашинников Ю.К. Физическая география Дальнего Востока России. Владивосток: Изд-во Дальневост. ун-та, 1999. 324 с.

11. Куликова В.В. Стихийные и катастрофические и их экологические последствия (на примере юга Дальнего Востока). Находка: Изд-во ИТИБ, 2006. 136 с.

12. Наумов Ю.А. Антропогенез и экологическое состояние геосистемы прибрежно-шельфовой зоны залива Петра Великого Японского моря. Владивосток: Дальнаука, 2006. 300 с.

13. Шестёркин В.П., Шестёркина Н.М. Гидрохимическая характеристика реки Уссури // Вопросы гидрологии и гидроэкологии Урала: сб. науч. тр., Пермь, 2009. С. 73-77. 


\section{Транслитерация по ГОСТ 7.79-2000 система Б}

1. Doklad o sostoyanii okruzhayushhej sredy v Amurskoj oblasti v 2019 godu. Blagoveshhensk: Ministerstvo prirodnykh resursov i ehkologii Ámurskoj oblasti, 2020. $136 \mathrm{~s}$.

2. Doklad o sostoyanii okruzhayushhej sredy v Evrejskoj avtonomnoj oblasti v 2017 godu. Birobidzhan: Ministerstvo prirodnykh resursov i ehkologii Evrejskoj avtonomnoj oblasti, 2020. $142 \mathrm{~s}$.

3. Doklad o sostoyanii okruzhayushhej sredy v Kamchatskom krae v 2018 godu. Petropavlovks-Kamchatskij: Ministerstvo prirodnykh resursov i ehkologii Kamchatskogo kraya, 2019. $370 \mathrm{~s}$.

4. Doklad o sostoyanii okruzhayushhej sredy v Magadanskoj oblasti v 2015 godu. Magadan: Ministerstvo prirodnykh resursov i ehkologii Magadanskoj oblasti, 2020. $187 \mathrm{~s}$.

5. Doklad o sostoyanii okruzhayushhej sredy v Primorskom krae v 2019 godu. Vladivostok: Departament prirodnykh resursov i ehkologii Primorskogo kraya, 2020. $221 \mathrm{~s}$.

6. Doklad o sostoyanii okruzhayushhej sredy v Sakhalinskoj oblasti v 2019 godu. YUzhno-Sakhalinsk: Ministerstvo prirodnykh resursov i ehkologii Sakhalinskoj oblasti, 2020. 170 s.

7. Doklad o sostoyanii okruzhayushhej sredy v KHabarovskom krae v 2019 godu. KHabarovsk: Ministerstvo prirodnykh resursov i ehkologii KHabarovskogo kraya, 2020. 208 s.

8. Doklad o sostoyanii okruzhayushhej sredy v CHukotskom avtonomnom okruge v 2017 godu. Anadyr': Ministerstvo prirodnykh resursov i ehkologii CHukotskogo avtonomnogo okruga, 2018. $117 \mathrm{~s}$.

9. Dolgovremennaya programma okhrany prirody i ratsional'nogo ispol'zovaniya prirodnykh resursov Primorskogo kraya do 2005 goda. EHkologicheskaya programma. CHast' 2. Vladivostok: Dal'nauka, 1993. 301 s.

10. Ivashinnikov YU.K. Fizicheskaya geografiya Dal'nego Vostoka Rossii. Vladivostok: Izd-vo Dal'nevost. un-ta, 1999. 324 s.

11. Kulikova V.V. Stikhijnye i katastroficheskie i ikh ehkologicheskie posledstviya (na primere yuga Dal'nego Vostoka). Nakhodka: Izd-vo ITIB, 2006. 136 s.

12. Naumov YU.A. Antropogenez i ehkologicheskoe sostoyanie geosistemy pribrezhno-shel'fovoj zony zaliva Petra Velikogo YAponskogo morya. Vladivostok: Dal'nauka, 2006. $300 \mathrm{~s}$.

13. SHestyorkin V.P., SHestyorkina N.M. Gidrokhimicheskaya kharakteristika reki Ussuri // Voprosy gidrologii i gidroehkologii Urala: sb. nauch. tr., Perm', 2009. S. 73-77.

Наумов Ю. А. Об особенностях загрязнения поверхностных вод на территории Дальнего Востока России.

Статья посвящена изучению особенностей загрязнения поверхностных вод в каждом субъекте Дальнего Востока России. Автор акцентирует внимание на экологическом состоянии рек, озер, водохранилищ, увеличении степени загрязнения региона от всё возрастающей химизации со стороны бурно развивающегося Китая.

Ключевые слова:загрязнение поверхностных вод, антропогенное воздействие, поллютанты, экологическая обстановка

\section{Far East. \\ Naumov Yu. A. On the features of surface water pollution in the Russian \\ The article is devoted to the study of the features of surface water pollution in each subject of the Russian Far East. The author focuses on the ecological state of rivers, lakes, reservoirs, an increase in the degree of pollution of the region from the ever-increasing chemicalization, from the rapidly developing China.} situation

Key words: pollution of surface waters, anthropogenic impact, pollutants, ecological

Для цитирования: Наумов Ю. А. Об особенностях загрязнения поверхностных вод на территории Дальнего Востока России // Ойкумена. Регионоведческие исследования. 2021. № 3. C. 102-112. DOI: 10.24866/1998-6785/2021-3/102-112

For citation: Naumov Yu. A. On the features of surface water pollution in the Russian Far East // Ojkumena. Regional researches. 2021. № 3. P. 102-112. DOI: 10.24866/1998-6785/20213/102-112 